\title{
CEPAEA NEMORALIS (L.) ON ÖLAND, SWEDEN: RECENT INVASION AND UNEXPECTED VARIATION
}

\author{
Robert A. D. CAMERON ${ }^{1,2 *}$, TeD VON ProsChWitZ ${ }^{3,4}$
}

\begin{abstract}
${ }^{1}$ Department of Animal and Plant Sciences, University of Sheffield, Sheffield S10 2TN, United Kingdom ${ }^{2}$ Department of Zoology, the Natural History Museum, London SW7 5BD, United Kingdom (e-mail: r.cameron@sheffield.ac.uk) ${ }^{3}$ Göteborg Natural History Museum, PO Box 7283, SE-40235 Göteborg, Sweden ${ }^{4}$ Gothenburg Global Biodiversity Centre, University of Gothenburg, Box 46, SE-40530 Göteborg, Sweden *corresponding author
\end{abstract}

\begin{abstract}
Cepaea nemoralis is a recently introduced species on Öland. Discounting an early and debateable record, the species has been recorded only in the 21st century, despite intensive earlier faunistic surveys. A recent survey has yielded records from the whole length of the island $(137 \mathrm{~km})$, but the majority of known populations are in its southern half, most particularly around the settlements of Mörbylånga, Gräsgård and Färjestaden. Populations are usually in anthropogenic habitats. Most appear small and isolated by less disturbed areas. Nearly all samples are polymorphic for both colour and banding morphs, and the variation among populations is low when compared with similar sets from other places where recent colonisation has occurred. There is no latitudinal variation in morph frequencies, nor is any spatial autocorrelation apparent. While a relatively uniform and rigorous selection regime could account for the patterns seen, a single initial introduction followed by transport of propagules large enough to minimise founder effects is also possible.
\end{abstract}

KeY WORDS: introduced species; Cepaea nemoralis; shell polymorphism; Öland; Sweden

\section{INTRODUCTION}

The polymorphic European land snail Cepaea nemoralis (L.) has become a "model organism" in the study of visible genetic variation within and among populations (OŻGO 2008, 2012, Rosin et al. 2011, COOK 2017). These studies involve the famous shell colour and banding polymorphism (JONES et al. 1977, COOK 1998). The genetics of much of this variation is known, though that of minor variation in number of bands and of fusions among them remains undetermined (summary in JONES et al. 1977). Both within the natural range and elsewhere, numerous surveys at many scales have identified patterns of variation in which various selective agencies, are implicated, most significantly those caused by predation and climate (SILVERTOWN et al. 2011, CAMERON 2016).

There is, however, evidence that population history involving bottlenecks and founder effects influence morph frequencies. In more general terms, ge- netic drift may be significant both in influencing the amount of variation within populations and the magnitude of differences between them. The interaction of these processes is often complex, even within the natural range, within which there have been significant environmental changes (CAMERON \& DILLON 1984, CAMERON \& PANNETT 1985). The balance and interaction of these processes in relation to the circumstances of the populations enhances our understanding of evolution at the most basic level (OżGO 2008, COOK 2017).

C. nemoralis is a species with a wide ecological tolerance. It is frequently abundant in very anthropogenic habitats, and it is easily spread accidentally, perhaps most often with horticultural products. Most evidently in the last three or four decades, it has been expanding its range both into urban areas previously too polluted to sustain it (CAMERON et al. 2009) and 
more generally into largely anthropogenic and urban habitats to the north and east of its natural range (OżGo 2005, CAMERON et al. 2011, PeltanOvÁ et al. 2012, POKRYSZKO et al. 2012, GHEOCA 2018, OżGO et al. 2019, GURAL-SVERLOVA et al. 2020), extending as far east as Moscow (EGOROV 2018).

Sweden is thought to lie outside the original, natural range of $C$. nemoralis, although the extreme south, Skåne, has been occupied for several centuries (WALDÉN 1986). It was deliberately or accidentally introduced to a few places further to the north in the 19th century (CAMERON et al. 2014, CAMERON \& VON PROSCHWITZ 2019), but remained restricted until late into the 20th century. Since then, it has spread not only from these sites, but has extended its range northwards. In 2013 it was found in Härnösand [62 $\left.38^{\prime} \mathrm{N}\right]$ (VON PROSCHWITZ 2015), and in 2020 as far north as in Umeå [63⒋'N] (data from the Swedish Species Information Centre).
Studies on the shell colour and banding polymorphism of these recently established populations of C. nemoralis (cited above) have revealed patterns of variation that demonstrate the influence of founder effects or genetic drift, a product of long-distance transport followed by local dispersal, the latter certainly aided by human activity. The Swedish island of Öland had only one, disputed, record of $C$. nemoralis earlier than the 21st century, despite many intensive faunistic surveys. Populations are now known from the whole length of the island, though populations appear to be small and isolated from one another. We report here on surveys conducted over the last 10 to 15 years that reveal an unexpected pattern of variation somewhat discordant with patterns seen in other regions where the species is a recent arrival, and in particular in the cases of Göteborg (CAMERON et al. 2014) and the nearby island of Gotland (CAMERON \& VON PROSCHWITZ 2019).

\section{AREA STUDIED}

Öland is a long, thin island in the Baltic Sea (137 $\mathrm{km}$ north to south, and $16 \mathrm{~km}$ across at its widest, centred on $56^{\circ} 40^{\prime}$ north and $16^{\circ} 40^{\prime}$ east) lying parallel to the eastern coast of mainland Sweden (Fig. 1A).
While containing the same Silurian limestone scenery as its northern neighbour Gotland, it is smaller $\left(1,342 \mathrm{~km}^{2}\right.$ versus $\left.3,183 \mathrm{~km}^{2}\right)$, flatter (highest point, $55 \mathrm{~m}$ a.s.l. versus $82 \mathrm{~m}$ ) and with a drier and warm-

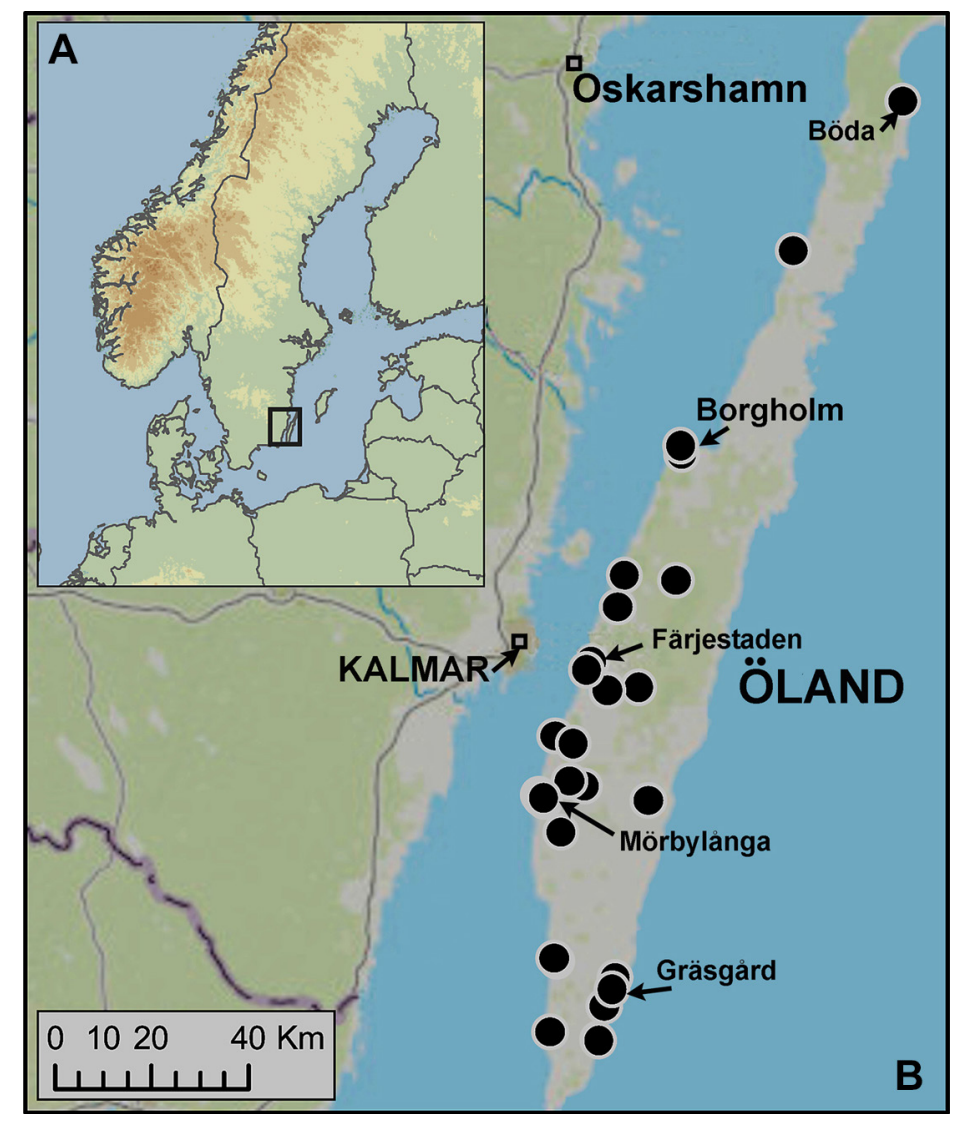

Fig. 1. Research area: A - the position of Öland; B - the island of Öland, showing the location of sampling sites used in the study 
er climate (January mean temperature $+0.7-0.9{ }^{\circ} \mathrm{C}$ versus $-0.6{ }^{\circ} \mathrm{C}$, July, $20.9-21.6^{\circ} \mathrm{C}$ versus $17.9^{\circ} \mathrm{C}$, precipitation, $392-420 \mathrm{~mm}$ annually versus 525 $\mathrm{mm}$ on Gotland). Göteborg, much further west, is both cooler in summer and wetter than either island, with lower summer temperatures, less sunshine and double the precipitation of Öland. Populations of $C$. nemoralis so far discovered span the whole length of the island (Fig. 1B).

\section{EARLIER SURVEYS, MATERIAL AND METHODS}

All the samples of $C$. nemoralis used for analysis are held in the Natural History Museum of Göteborg (Appendix). Prior to surveys in the 21st century there is only one authenticated record of C. nemoralis, a sample of three yellow unbanded shells from the island's capital, Borgholm, collected in 1895 by an unknown person. It is not recorded in the comprehensive faunal account of WESTERLUND (1884), nor in his overview of the North European mollusc fauna (WESTERLUND 1897) and his supplement to the original 1884 fauna (WESTERLUND 1904). Hans Lohmander (1896-1961), who was curator at the Göteborg museum, performed extensive fieldwork on Öland in 1924, 1928, 1937, 1939 and 1941 (LOHMANDER 1937, 1938, 1940). He examined 943 localities on the island, none of which yielded $C$. nemoralis (VON PROSCHWITZ 1999). Further evidence for its absence in the first half of the 20th century comes from SCHLESCH (1937), reporting on his collecting experiences the previous year: " $\mathrm{C}$. nemoralis fehlt gänzlich" (totally absent).

There were no surveys on the same scale in the second half of the 20th century, but one of us (T. von Proschwitz) had visited and sampled on the island frequently from 1979 onwards. The first occasion on which he found C. nemoralis was in 2005 in the nature reserve Mysinga alvar near Resmo (VON PROSCHWITZ 2007). Unknown at the time, there was an earlier record made by G. Schmid in 2001, in a garden in Fäjestaden; this record, and another made by $\mathrm{T}$. von Proschwitz during the spring meeting of the German Malacological Society (Frühjahrstreffen der DMG) 2007 were published in the report from that meeting (VON PROSCHWITZ 2014).

The only record notionally from the 20th century is that of JAECKEL (1962): "Ins. [Inseln] Öland und Gotland" [Islands Öland and Gotland]. The basis on which he made this statement is not known, though he may have been aware of the 1895 record. WALDÉN (1966) refuted Jaeckel's claim ("nicht auf Öland"), and further doubted the authenticity of the locality for the 1895 record (in litt. to T. von Proschwitz).

With the exception of the 1895 record, all samples were made and scored by T. von Proschwitz. Scoring of colour and banding morphs followed the system used by JONES et al. (1977) with a full tally of bands present and the extent of fusions among them. We have used the standard categories of yellow, pink and brown for shell colour; for banding, we have used four standard categories of unbanded (00000), mid-banded (00300), trifasciate (00345) and many-banded (12345), with minor variants ascribed to the most appropriate category. Thus, for example, 00045 shells were allocated to the trifasciate class, and 10345 to the many-banded class. We have not considered the occurrence of fused bands as information about this is often absent from other studies, and is not always presented in a standard manner. Full details are, however, available from the Natural History Museum of Göteborg.

For analysis, only the 29 samples containing 10 or more scoreable shells were used. In two cases (Appendix) repeat samples from the same site have been combined. All were made in the 21 st century. We did not attempt to classify habitats by shading; they were all from rather heterogeneous anthropogenic sites. Frequencies of the colour morphs and of unbanded shells were calculated relative to the whole sample; for midbanded the frequencies are those within the banded shells; for trifasciate they are those within shells with more than one band, reflecting the dominance hierarchy at these loci (JONES et al. 1977). We used a modified version of $F_{\text {ST }}$ (WEIR \& COCKERHAM 1984) as a measure of variation among samples; it was corrected for sampling error and used morph- rather than allele frequencies, following CAMERON et al. (2009). Moran's I was used to test for spatial autocorrelation (CAMERON et al. 2014).

scoreable shells and the median only 14 . All major morphs were present on the island, and most populations were polymorphic at each locus (Table 1). Brown shells were present at only five sites and at are shown in Figure 1B. With only a few exceptions snails were hard to find; mean sample size was 19.7

\section{RESULTS}

The Appendix gives details of the location and composition of all 29 samples used. Site locations 
Table 1. Basic data on the frequencies of the major morphs in 29 samples of C. nemoralis from Öland

\begin{tabular}{lcccc}
\hline \multicolumn{1}{c}{ Frequency [\%] } & Yellow & Unbanded & $\begin{array}{c}\text { Midbanded } \\
\text { in banded }\end{array}$ & $\begin{array}{c}\text { Trifasciate } \\
\text { in many banded }\end{array}$ \\
\hline Mean & 41.9 & 51.6 & 61.6 & $32.7^{*}$ \\
Median & 43.6 & 53.8 & 63.6 & $33.3^{*}$ \\
Range & $0-85.7$ & $11.8-81.3$ & $0-100$ & $0-100^{*}$ \\
\hline \multicolumn{1}{c}{ Monomorphic } & Colour & Bands & Mid & Tri \\
Number of populations & 1 & 0 & $+/-$ & $1-$ \\
\% of populations & 3.4 & 0 & 31.0 & $47.8^{*}$ \\
Median sample size & 14 & 14 & 7 & 4 \\
\hline
\end{tabular}

* - many-banded shells were present in only 23 populations. Values relate only to those populations.

Table 2. Values of $\mathrm{F}_{\mathrm{ST}}$ corrected for sampling error and modified following CAMERON et al. (2009) for major loci on Öland and in other studies referred to in the text. Göteborg and Sheffield are recently colonised, with isolated populations. Wrocław has been occupied for longer and at greater density, while the area of central England (using data from SILVERTOWN et al. 2011, as also presented in CAMERON \& VON PROSCHWITZ 2019, open habitats only) contains well established populations within the natural range. Gdańsk represents an intermediate condition

\begin{tabular}{lccccccc}
\hline $\mathrm{F}_{\text {ST }}$ (corrected) & Öland & Gotland & Göteborg & Sheffield & Wrocław & Central England & Gdańsk \\
\hline Yellow & 0.107 & 0.037 & 0.212 & 0.207 & 0.089 & 0.116 & 0.165 \\
Unbanded & 0.071 & 0.271 & 0.302 & 0.350 & 0.092 & 0.096 & 0.185 \\
Mid in banded & 0.254 & 0.249 & 0.277 & 0.284 & 0.123 & 0.137 & 0.169 \\
Trifasciate & 0.248 & $\mathrm{n} / \mathrm{a}$ & 0.290 & $\mathrm{n} / \mathrm{a}$ & 0.111 & $\mathrm{n} / \mathrm{a}$ & $\mathrm{n} / \mathrm{a}$ \\
\hline
\end{tabular}

low frequency. There are no significant associations between any morph and latitude or longitude. Further, there are no signs of any spatial autocorrelation: values of Moran's I not only lack significance, but all values at all distances are close to zero (data not shown). Similarly, there are no among-sample associations between morphs, and linkage disequilibria between the colour and banding loci are slight, and are equally distributed in opposite directions. Values of $\mathrm{F}_{\mathrm{ST}}$ for colour and for unbanded are low relative to values obtained in other studies on introduced populations (Table 2; see discussion below). Those for mid-banded and trifasciate are higher, but given the very small number of shells on which they are based (medians of seven and four shells per sample, respectively) they may be less than reliable even with sample size correction.

\section{DISCUSSION}

On the evidence available, the populations of $C$. nemoralis recorded on Öland are of very recent origin, most probably stemming from introduction very late in the 20th century. While we cannot absolutely discount the record of 1895, it is notable that intensive surveys over nearly 50 years thereafter failed to yield more records, in contrast to the situation in Göteborg (CAMERON et al. 2014) or on Gotland (CAMERON \& VON PROSCHWITZ 2019), where 19th century records were followed by further observations, even if numbers and sites remained limited until the late 20th century.

This pattern of late 20th and then 21 st century spread is found repeatedly as the species continues to advance northwards in Sweden. It is paralleled by rapid contemporaneous expansion into urban and anthropogenic habitats elsewhere, as documented in the introduction. Arrival and spread on Öland is very much in accord with the general trend.

The pattern of variation in C. nemoralis on Öland, however, does not conform to that usually found among such recent, colonising populations, where $\mathrm{F}_{\text {ST }}$ is high, and spatial autocorrelation at small scales is often strong (e.g. CAMERON et al. 2014). Despite small sample sizes, and the apparent isolation of individual populations, most remain polymorphic at the major loci (Table 1). The range of among population variation, as estimated by $\mathrm{F}_{\mathrm{ST}}$ (Table 2 ) is limited, at least for the more reliable estimates for shell colour and the presence or absence of bands. They resemble values obtained from central England, where selection for crypsis is well-documented and populations are long-standing and frequently continuous, or from urban populations with greater connectivity and large population sizes such as Wrocław (CAMERON et al. 2009). The contrast with Göteborg on all these measures is striking, as is the lack of spatial autocorrelation, which was manifest in the distribution of 
brown shells and the frequency of banding variants in the city (CAMERON et al. 2014), and has also been found frequently elsewhere, even in areas within the natural range, and in stable habitats (CAMERON \& PANNETT 1985, POKRYSZKO et al. 2012).

The repeated patterns of variation in freshly colonised regions (high values of $\mathrm{F}_{\mathrm{ST}}$ and strong spatial autocorrelation over short distances) have been related to long distance transport of small numbers, with later small-scale migration or transport, involving founder effects and genetic drift, with minimal gene flow between populations. There is no evidence that the process of colonisation on Öland is in any way unique, while the pattern of variation is very different. While the limited number of samples, and their small size enforce caution, the striking difference between Öland and most other recently colonised regions suggests two possible explanations. Assuming a single introduction event, then if actual population sizes remain large and the numbers transported to new sites on the island are adequate, deviation from the original composition will be modest in the absence of differing selection pressures among sites. While a single introduction event is plausible, sampling to date gives no grounds for assuming large or interconnected populations (nor, conclusively, to reject the idea). The limestone bedrock may indeed facilitate dispersal, but the snail has not been found in sites away from human disturbance.

The other possibility is that variation is constrained by selection of a kind that is relatively uniform across the island. In this context, we can note that while the median frequencies of colour morphs differ only slightly among the nearest comparable surveys (Table 3 ), the frequency of unbanded and effectively unbanded shells is significantly higher on Öland than elsewhere in the region, and remarkably uniform across samples $\left(\mathrm{F}_{\mathrm{ST}}\right.$ for this genetically heterogeneous category is only 0.062, cf. Table 2). The island is drier, sunnier and warmer in summer than Gotland, and much more so than Göteborg or Gdańsk. Öland, indeed, resembles locations at the southern limits of the snail's natural distribution in terms of sunshine and precipitation, though not summer temperatures.

The evidence that such environmental conditions favour such effectively unbanded shells (excluding
Table 3. The mean frequencies of yellow, unbanded and "effectively unbanded" (top two bands missing) shells in samples of $C$. nemoralis from Öland, and in the three nearest regions in which surveys have been carried out. Gotland is c. $70 \mathrm{~km}$ distant, Göteborg and Gdańsk ca. $320 \mathrm{~km}$ distant (west and south respectively). Data from CAMERON et al. (2011), CAMERON et al. (2014) and CAMERON \& VON PROSCHWITZ (2019). Figures for Gdańsk refer to open habitats only

\begin{tabular}{lcccc}
\hline & Öland & Gotland & Göteborg & Gdańsk \\
\hline Yellow & 41.9 & 54.6 & 38.1 & 45.5 \\
Unbanded & 51.6 & 29.6 & 5.6 & 29.0 \\
$\begin{array}{l}\text { Effectively } \\
\text { unbanded }\end{array}$ & 87.7 & 64.6 & 63.8 & 69.0 \\
\hline
\end{tabular}

brown shells) is equivocal; in some regional comparisons, the frequencies of effectively unbanded shells in open habitats are higher in the sunnier, hotter and drier regions (LAMOTTE 1966, ARNOLD 1969), and there is some evidence that the lack of bands on the upper part of the shell, reflecting more sunlight, moderates temperature increase when exposed (EMBERTON \& BRADBURY 1963, LAMOTTE 1966). More generally, dark shells, with bands as a darkening feature as well as shell colour, may reach higher equilibrium temperatures in sunlight (HEATH 1975, TILLING 1983). In broader comparisons, however, such associations are far from universal (JONES et al. 1977), and the many other factors affecting morph frequencies have obscured any general trend that might occur when the whole range is considered (SILVERTOWN et al. 2011). Our purpose is not to make a claim, but to point to possibilities, given the unusual pattern of variation in this particular set of introduced and expanding populations. Further work will provide more clarity, and the data are available as a basis for such studies.

\section{ACKNOWLEDGEMENTS}

We thank MICHAL HORSÁK for computing values of Moran's I and VERONIKA HORSÁKOVA for composing the maps of Figure 1. TORSTEN NORDANDER (former curator in the Göteborg Natural History Museum and with great knowledge of Öland) gave valuable hints of where to search for $C$. nemoralis on the island. Two reviewers made helpful comments.

\section{REFERENCES}

ARNOLD R. 1969. The effects of selection by climate on the land-snail Cepaea nemoralis (L.). Evolution 23: 370-378. https://doi.org/10.1111/j.1558-5646.1969.tb03521.x

CAMERON R. A. D. 2016. Slugs and snails. HarperCollins, London.
CAmeron R. A. D., Cox R. J., Proschwitz T. VON, HoRsÁK M. 2014. Cepaea nemoralis (L.) in Göteborg, S.W. Sweden: variation in a recent urban invader. Folia Malacologica 22: 169-182. https://doi.org/10.12657/ folmal.022.016 
CAmeron R. A. D., Dillon P. 1984. Habitat stability, population histories and patterns of variation in Cepaea. Malacologia 25: 271-290.

CAmeron R. A. D., OżGo M., Horsák M., Bogucki Z. 2011. At the north-eastern extremity: variation in Cepaea nemoralis around Gdańsk, northern Poland. Biologia 66: 1097-1113. https://doi.org/10.2478/ s11756-011-0128-9

CAmeron R. A. D., PANNETT D. J. 1985. Interaction between area effects and variation with habitat in Cepaea. Biological Journal of the Linnean Society 24: 365-379. https://doi.org/10.1111/j.1095-8312.1985.tb00382.x

CAmeron R. A. D., PokryszKo B. M., Horsák M. 2009. Contrasting patterns of variation in urban populations of Cepaea (Gastropoda: Pulmonata): a tale of two cities. Biological Journal of the Linnean Society 97: 27-39. https://doi.org/10.1111/j.1095-8312.2008.01187.x

CAmeron R. A. D., Proschwitz T. vON 2019. Cepaea nemoralis (L.) on Gotland, Sweden: spread and variation. Folia Malacologica 27: 307-313. https://doi. org/10.12657/folmal.027.027

CoOK L. M. 1998. A two-stage model for Cepaea polymorphism. Philosophical Transactions of the Royal Society B 353: 1577-1593. https://doi.org/10.1098/ rstb.1998.0311

CoOK L. M. 2017. Reflections on molluscan shell polymorphisms. Biological Journal of the Linnean Society 121: 717-730. https://doi.org/10.1093/biolinnean/blx033

EGOROV R. 2018. On the distribution of introduced species of the genus Cepaea Held, 1838 (Gastropoda: Pulmonata: Helicidae) in European Russia. Nachrichtenblatt der Ersten Vorarlberger Malakologischen Gesellschaft 25: 79-102.

EMBERTON L. R. B., BRADBURY S. 1963. Transmission of light through shells of Cepaea nemoralis (L.). Proceedings of the Malacological Society of London 35: 211-219.

GHEOCA V. 2018. The first record of Cepaea nemoralis (Linnaeus, 1758) (Stylommatophora: Helicidae) from Romania. Acta Zoologica Bulgarica 70: 129-130.

Gural-Sverlova N. V., Gural R. I., SAVChuK S. P. 2020. Novye nakhodki Cepaea nemoralis (Gastropoda, Pulmonata, Helicidae) i pheneticheskaya struktura koloniy etogo vida na zapade Ukrainy. Ruthenica, Russian Malacological Journal 30: 75-86.

HEATH D. J. 1975. Colour, sunlight and internal temperatures in the land snail Cepaea nemoralis (L.). Oecologia 19: 29-38. https://doi.org/10.1007/BF00377587

JAECKELS. G. A. JNR 1962. Ergänzungen und Berichtigungen zum rezenten und quartären Vorkommen der mitteleuropäischen Mollusken. In: BROHMER P., EHRMANN P., Ulmer G. (eds). Die Tierwelt Mitteleuropas 2 (Ergänzung). Von Quelle \& Meyer, Leipzig, pp. 25-294.

JONES J. S, LEITH B. H., RAWLINGS P. 1977. Polymorphism in Cepaea: a problem with too many solutions? Annual Review of Ecology and Systematics 8: 109-143. https:// doi.org/10.1146/annurev.es.08.110177.000545

LAMOTTE M. 1966. Les facteurs de la diversité du polymorphisme dans les populations naturelles de Cepaea nemoralis (L.). Lavori della Società Malacologica Italiana 3: 33-73.

LOHMANDER H. 1937. Fältarbeten 1936. In: NYBELIN O. (ed.). Naturhistoriska Museet. Berättelse för år 1937. Göteborgs Musei Årstryck 1937: 17-21.

LOHMANDER H. 1938. Amanuens Hans Lohmanders redogörelse för årets fältarbeten i Danmark och på Öland. In: NYBELIN O. (ed.). Naturhistoriska Museet. Berättelse för 1937. Göteborgs Musei Årstryck 1938: 18-24.

LOHMANDER H. 1940. Amanuens Hans Lohmanders redogörelse för årets fältarbeten på Kinnekulle och omgivande trakt samt på Bornholm och Öland. In: NYBELIN O. (ed.). Göteborgs Museum, Zoologiska avdelningen. Berättelse för år 1939, Göteborg, pp. 1820.

OżGO M. 2005. Cepaea nemoralis (L.) in southeastern Poland: association of morph frequencies with habitat. Journal of Molluscan Studies 71: 93-103. https://doi. org/10.1093/mollus/eyi012

OżGO M. 2008. Current problems in the research of Cepaea polymorphism. Folia Malacologica 16: 55-60. https:// doi.org/10.12657/folmal.016.009

OżGO M. 2012. Shell polymorphism in the land-snail Cepaea nemoralis (L.) along a West-East transect in continental Europe. Folia Malacologica 20: 181-253. https://doi.org/10.2478/v10125-012-0015-1

Ożgo M., CAMERon R. A. D., HorsáK M., POKRYSzKo B. M., CHUdAŚ M., CiCHY A., KACZMAREK S., KOBAK J., MARZEC M., MierZWA-SZYMKOWIAK D., PARZONKO D., PyKa G., Rosin Z., SKaWINA A., SOROKA M., SULIKOWSKA-DROZD A., SUROWIEC T., SZYMANEK M., TEMPlin J., URBAŃSKA M., ZAJĄC K., ZiELSKA J., ŻBIKOWSKA E., ŻOŁĄDEK J. 2019. Cepaea nemoralis (Gastropoda: Pulmonata) in Poland: patterns of variation in a range-expanding species. Biological Journal of the Linnean Society 127: 1-11. https://doi. org/10.1093/biolinnean/blz029

PELTANOVÁ A., DVOŘÁK L., JUŘIČKOVÁ L. 2012. The spread of non-native Cepaea nemoralis and Monacha cartusiana (Gastropoda: Pulmonata) in the Czech Republic with comments on other land snail immigrants. Biologia 67: 384-389. https://doi.org/10.2478/s11756-012-0020-2

PokryszKo B. M., CAmeron R. A. D., HorsáK M. 2012. Variation in the shell colour and banding polymorphism of Cepaea nemoralis (L.) in rural areas around Wrocław. Folia Malacolologica 20: 87-98. https://doi. org/10.2478/v10125-012-0012-4

PROSCHWITZ T. VON 1999. Landlevande mollusker i Kalmar län II. Öland - Förslag till utnyttjande av data från Göteborgs Naturhistoriska Museums markfaunainventering i miljöövervakningsstudier. Sammanställningar av lokaler för rödlistade och sällsynta arter, samt lokaler med höga naturvärden. Länsstyrelsen Kalmar län informerar. Meddelande 1999: 13, 143 pp.

Proschwitz T. VON 2007. Fünf für die Ostseeinsel Öland neue Landschneckenarten: Vertigo liljeborgi (Westerlund), Xerolenta obvia (MENKE), Candidula unifasciata (POIRET), Cepaea nemoralis (LINNAEUS) und Helix pomatia LINNAEUS. Heldia 5 (3): 75-79. 
Proschwitz T. VON 2014. Bericht über die 46. Frühjahrstagung der Deutschen Malakozoologischen Gesellschaft in Vickleby auf der Ostseeinsel Öland (Schweden) von 25. Bis 28. Juni 2007. Mitteilungen der deutschen malakozoologischen Gesellschaft 90: 1-12.

Proschwitz T. VON 2015. Faunistical news from the Göteborg Natural History Museum 2014 - snails, slugs and mussels. Göteborgs Naturhistoriska Museum Årstryck 2015: 31-46.

Rosin Z. M., OlborsKa P., SURMACKI A., TRYJANOWSKI P. 2011. Differences in predatory pressure on terrestrial snails by birds and mammals. Journal of Biosciences 36 : 691-699. https://doi.org/10.1007/s12038-011-9077-2

SCHLESCH H. 1937. Beitrag zur Molluskenfauna Öland's. Archiv für Molluskenkunde 69: 19-23.

Silvertown J., CoOK L. M., CAmeron R. A. D., DodD M., MCCONWAY K., WORTHINGTON J., SKELTON P., ANTON C., BOSSDORF O., BAUR B., SCHILTHUIZEN M., Fontaine B., SATtMANN H., Bertorelle G., Correia M., Oliveira C., POKRYSZKO B., OŻGO M., StalažS A., Gill E., RAmmul Ü., SÓlymos P., FÉHer Z., JUAN X. 2011. Citizen science reveals unexpected continental-scale evolutionary change in a model organism. PLoS ONE 6: e18927. https://doi.org/10.1371/journal. pone.0018927

TILlING S. M. 1983. An experimental investigation of the behaviour and mortality of artificial and natural morphs of Cepaea nemoralis (L.). Biological Journal of the Linnean Society 19: 35-50. https://doi org/10.1111/j.1095-8312.1983.tb00775.x
WALDÉN H. W. 1966. Einige Bemerkungen zum Ergänzungsband zu EHRMANN's "Mollusca" in "Die Tierwelt Mitteleuropas". Archiv für Molluskenkunde 95: 49-68.

WALDÉN H. W. 1986. A comprehensive account of the late Quaternary land Mollusca in Sweden. Malakologische Abhandlungen Staatliches Museum für Tierkunde in Dresden 11: 105-133.

WEIR B. S., COCKERHAM C. C. 1984. Estimating F-statistics for the analysis of population structure. Evolution 38: 1358-1370. https://doi.org/10.1111/j.1558-5646.1984. tb05657.x

WeSTERLUND C. A. 1884. Sveriges, Norges, Danmarks och Finlands land-och sötvattenmollusker. Exkursionsfauna. Central-Tryckeriet, Stockholm.

Westerlund C. A. 1897. Synopsis Molluscorum Extramarinorum Scandinaviae (Sueciae, Norwegiae, Daniae et Fenniae). Acta Societatis pro Fauna et Flora Fennica 13(7): 4-238. https://doi.org/10.5962/bhl.title. 11407

Westerlund C. A. 1904. Sveriges, Norges, Danmarks och Finlands land-och sötvattenmollusker. Exkursionsfauna. Tillägg [Supplement]. A. Bonnier, Stockholm.

Received: September 2nd, 2020

Revised: November 5th, 2020

Accepted: November 6th, 2020

Published on-line: December 4th, 2020 


\section{APPENDIX}

Samples of Cepaea nemoralis (L.) made on Öland. Longitude and latitude given in DDM. For the date of sampling, two sites were sampled on more than one occasion

\begin{tabular}{|c|c|c|c|c|c|c|c|c|c|c|c|c|c|c|}
\hline Longitude & Latitude & Date & $1 \mathrm{st}$ & $\mathrm{N}$ & P0 & P3 & $\begin{array}{l}\mathrm{P} \\
\text { tri }\end{array}$ & P5 & Y0 & Y3 & $\begin{array}{l}\mathrm{Y} \\
\text { tri }\end{array}$ & Y5 & B0 & Locality \\
\hline $16^{\circ} 39.36^{\prime}$ & $56^{\circ} 52.80^{\prime}$ & 1895 & & 3 & & & & & 3 & & & & & Borgholm \\
\hline $16^{\circ} 28.38^{\prime}$ & $56^{\circ} 32.16^{\prime}$ & 2005-2020 & 2005 & 14 & 1 & 1 & & & 6 & 3 & 1 & 2 & & Resmo, $750 \mathrm{~m} \mathrm{WNW}$ of p.39.22 \\
\hline $16^{\circ} 27.06^{\prime}$ & $56^{\circ} 34.80^{\prime}$ & 30.06 .2020 & & 11 & 1 & & 1 & 2 & 6 & & 1 & 1 & & $\begin{array}{l}\text { Vickleby, } 500 \mathrm{~m} \text { WNW of the } \\
\text { church }\end{array}$ \\
\hline $16^{\circ} 26.82^{\prime}$ & $56^{\circ} 39.90^{\prime}$ & 01.07 .2020 & 2001 & 11 & 3 & & & & 2 & 3 & & 3 & & $\begin{array}{l}\text { Torslunda, Färjestaden, } \\
\text { Paradisgatan }\end{array}$ \\
\hline $16^{\circ} 23.46^{\prime}$ & $56^{\circ} 31.44^{\prime}$ & 30.06 .2020 & & 29 & 4 & 4 & 1 & 2 & 9 & 5 & 2 & 2 & & Mörbylånga, Trollstigen \\
\hline $16^{\circ} 34.38^{\prime}$ & $56^{\circ} 38.22^{\prime}$ & 01.07 .2020 & 2018 & 10 & & 3 & & 1 & 2 & 3 & 1 & & & $\begin{array}{l}\text { Torslunda, } 400 \mathrm{~m} \text { NNW of } \\
\text { Hildeborg }\end{array}$ \\
\hline $16^{\circ} 23.88^{\prime}$ & $56^{\circ} 31.20^{\prime}$ & $2015-2020$ & 2015 & 87 & 15 & 8 & 2 & 8 & 35 & 8 & 1 & 8 & 2 & Mörbylånga, cemetery \\
\hline $16^{\circ} 26.64^{\prime}$ & $56^{\circ} 32.46^{\prime}$ & 28.06 .2020 & & 18 & 5 & 1 & 1 & & 8 & 1 & & 1 & 1 & Resmo, cemetery \\
\hline $16^{\circ} 30.00^{\prime}$ & $56^{\circ} 16.50^{\prime}$ & 01.07 .2020 & 2012 & 13 & 4 & 2 & & & 3 & 2 & & 2 & & Gräsgård, Össby, in the harbour \\
\hline $16^{\circ} 39.06^{\prime}$ & $56^{\circ} 52.98^{\prime}$ & 24.06 .2020 & & 28 & 8 & & & 6 & 9 & & & 5 & & Borgholm, cemetery \\
\hline $16^{\circ} 35.46^{\prime}$ & $56^{\circ} 31.26^{\prime}$ & 30.06 .2020 & & 14 & 4 & 2 & & 2 & 5 & & & 2 & & $\begin{array}{l}\text { Stenåsa, } 870 \mathrm{~m} \mathrm{~W} \text { of St. } \\
\text { Brunneby }\end{array}$ \\
\hline $16^{\circ} 31.44^{\prime}$ & $56^{\circ} 19.68^{\prime}$ & 01.07 .2020 & 2013 & 12 & 4 & 2 & & & 3 & 2 & 1 & & & $\begin{array}{l}\text { Gräsgård, Gammalsby, } 350 \mathrm{~m} \mathrm{~S} \text { of } \\
\text { the crossroad }\end{array}$ \\
\hline $17^{\circ} 03.78^{\prime}$ & $57^{\circ} 13.86^{\prime}$ & 01.07 .2020 & & 13 & 7 & & & & 2 & 4 & & & & Böda, Mellböda, recycling centre \\
\hline $16^{\circ} 24.96^{\prime}$ & $56^{\circ} 21.54^{\prime}$ & 01.07 .2020 & 2011 & 16 & 4 & 3 & & 2 & 3 & 2 & 1 & 1 & & $\begin{array}{l}\text { S. Möckleby, } 600 \mathrm{~m} \mathrm{NW} \text { of the } \\
\text { church }\end{array}$ \\
\hline $16^{\circ} 29.82^{\prime}$ & $56^{\circ} 16.56^{\prime}$ & 01.07.2020 & 2012 & 16 & 4 & 4 & & 1 & 2 & 3 & 2 & & & Gräsgård, Össby, in the village \\
\hline $16^{\circ} 23.82^{\prime}$ & $56^{\circ} 31.44^{\prime}$ & 30.06 .2020 & 2015 & 39 & 9 & 8 & 3 & 2 & 9 & & 6 & 2 & & Mörbylånga, Drömstigen \\
\hline $16^{\circ} 25.32^{\prime}$ & $56^{\circ} 21.36^{\prime}$ & 29.06 .2020 & & 12 & 6 & 1 & & & 2 & 3 & & & & S. Möckleby, cemetery \\
\hline $16^{\circ} 30.90^{\prime}$ & $56^{\circ} 38.04^{\prime}$ & 28.06 .2020 & & 39 & 10 & 12 & & 1 & 2 & 8 & 5 & 1 & & Torslunda, cemetery \\
\hline $16^{\circ} 32.04^{\prime}$ & $56^{\circ} 43.14^{\prime}$ & 28.06 .2020 & & 17 & 2 & 5 & 3 & 1 & & 2 & & 4 & & Glömminge, cemetery \\
\hline $16^{\circ} 28.98^{\prime}$ & $56^{\circ} 39.84^{\prime}$ & 30.06 .2020 & & 17 & 5 & 4 & & 2 & 4 & 2 & & & & $\begin{array}{l}\text { Algutsrum, Mölltorp, } \\
\text { Basilkagränd }\end{array}$ \\
\hline $16^{\circ} 38.52^{\prime}$ & $56^{\circ} 44.76^{\prime}$ & 27.06 .2020 & 2007 & 12 & 4 & 4 & & & 2 & 2 & & & & Långlöt, Ismantorp's fortress \\
\hline $16^{\circ} 23.16^{\prime}$ & $56^{\circ} 31.68^{\prime}$ & 27.06 .2020 & & 17 & 6 & 3 & 1 & & 3 & 1 & & 1 & 2 & $\begin{array}{l}\text { Mörbylånga, } 770 \mathrm{~m} \mathrm{E} \text { of the guest } \\
\text { harbour }\end{array}$ \\
\hline $16^{\circ} 51.66^{\prime}$ & $57^{\circ} 40.80^{\prime}$ & 25.06 .2020 & 2014 & 31 & 9 & 8 & & 4 & 8 & & & 1 & 1 & $\begin{array}{l}\text { Persnäs, Sandvik, } 1 \mathrm{~km} \mathrm{NNE} \mathrm{of} \\
\text { the pire }\end{array}$ \\
\hline $16^{\circ} 32.82^{\prime}$ & $56^{\circ} 45.06^{\prime}$ & 30.06 .2020 & 2011 & 14 & 2 & 8 & & & 2 & & & 2 & & Glömminge, 200 m ENE of Rosti \\
\hline $16^{\circ} 39.18^{\prime}$ & $56^{\circ} 52.44^{\prime}$ & 26.06 .2020 & 2015 & 16 & 11 & & & 1 & & & & 4 & & $\begin{array}{l}\text { Borgholm, Åkerhagen, Johan IIIs } \\
\text { väg }\end{array}$ \\
\hline $16^{\circ} 31.74^{\prime}$ & $56^{\circ} 20.34^{\prime}$ & 01.07.2020 & 2017 & 17 & 7 & 6 & & & 1 & 3 & & & & $\begin{array}{l}\text { Gräsgård, Selby, } 850 \mathrm{~m} \mathrm{NNE} \text { of } \\
\text { the crossroad }\end{array}$ \\
\hline $16^{\circ} 25.74^{\prime}$ & $56^{\circ} 29.34^{\prime}$ & 29.06 .2020 & & 11 & 5 & 2 & & & 2 & & & & 2 & Kastlösa, cemetery \\
\hline $16^{\circ} 25.08^{\prime}$ & $56^{\circ} 35.22^{\prime}$ & 01.07 .2020 & 2012 & 13 & 2 & 5 & 4 & & & 2 & & & & $\begin{array}{l}\text { Vickleby, Bejershamn, } 700 \text { m } \\
\text { NNE of Fröbygårda }\end{array}$ \\
\hline $16^{\circ} 30.48^{\prime}$ & $56^{\circ} 18.60^{\prime}$ & 29.06 .2020 & & 12 & 7 & 4 & & & 1 & & & & & Gräsgård, cemetery \\
\hline $16^{\circ} 24.48^{\prime}$ & $56^{\circ} 17.04^{\prime}$ & 29.06 .2020 & & 12 & 7 & 2 & & 3 & & & & & & Ventlinge, cemetery \\
\hline
\end{tabular}

1st - indicates date of first record for the site if prior to sampling; $\mathrm{N}$ - number of shells scored; P - pink shell colour; $\mathrm{Y}$ - yellow; B brown; 0 - unbanded; 3 - midbanded; tri - 00345; 5 - many bands with at least one of the upper two present. Data with full details of band variation, including fusions, is available from the Göteborg Museum of Natural History. The 1895 sample (in italics) is not included in analyses. 